\author{
Tadeusz Sucharski \\ Akademia Pomorska w Słupsku \\ tsucharski@wp.pl
}

\title{
Kobieta w łagrze stalinowskim w tekstach polskich pisarek
}

\section{A Woman in the Stalin's Lager as Seen in the Writings of Polish Women authors}

\begin{abstract}
The article is an attempt at a reflection on the record of the experiences of women in the Stalin's lagers. From the analytical perspective were reviewed the works of the Polish authors, inmates in the lagers: Beata Obertyńska, Barbara Skarga, Grażyna Lipińska, Herminia Naglerowa, Urszula Muskus. Their books constitute the most complete testimony of the lager experiences of women in the period of 1940-1955. These records were juxtaposed with the vision of a woman presented in Herling-Grudziński's $A$ World Apart, where in fact her role was confined to that of a sexual slave. The analysed works reveal much richer image of the everyday lager life of a woman. They do not question or reduce the role of sexual relations, but show the "fullness" of the lager existence of the inmates: their killing physical labour, the struggle for survival and preserving dignity, the desire for love and its horrible consequences. The analysis of the writings, however, forced the author to abandon the attempt to outline a general formula of the lager fate of a woman. Such attempt turned out to be impossible due to the fundamental differences in the status of particular lagers determined by the geographical span of the "Gulag Archipelago", and the differences in their organization resulting from the political changes in the USSR during 1940-1955.
\end{abstract}

Keywords: lagers, Gulag, totalitarian experiences, literature of the personal document

Streszczenie: Tekst jest próbą refleksji nad zapisem doświadczenia kobiety w łagrach stalinowskich. W perspektywie analitycznej znalazły się dzieła polskich autorek, więźniarek obozów: Beaty Obertyńskiej, Barbary Skargi, Grażyny Lipińskiej, Herminii Naglerowej, Urszuli Muskus. Ich książki stanowią najpełniejsze świadectwo doświadczenia łagrowego kobiety w piętnastoleciu 1940-1955. Zapisy owe zestawione zostały z wizją kobiety w Innym świecie Herlinga-Grudzińskiego, ograniczonej właściwie do roli niewolnicy seksualnej. Analizowane dzieła przynoszą znacznie bogatszy obraz łagrowej codzienności kobiety: nie kwestionując ani nie ograniczając znaczenia kontaktów seksualnych, pokazują jednak „pełnię” obozowej egzystencji więźniarek: ich morderczą pracę fizyczną, walkę o przetrwanie, o zachowanie godności, pragnienie miłości i jej straszliwe konsekwencje. Analiza tekstów zmusza jednak do rezygnacji z próby wypracowania jakiejś ogólnej formuły łagrowego losu kobiety. Próbę taką uniemożliwiają zasadnicze różnice w statusie obozów pokazanych w książkach, deter- 
minowane rozpiętością geograficzną Archipelagu GUŁag, różnicami w organizacji łagrów, wynikających ze zmian politycznych w ZSRR w latrach 1940-1955.

Słowa kluczowe: łagry, GUŁag, doświadczenie totalitarne, literatura dokumentu osobistego

W zakończeniu wstępu do Dymów nad Birkenau Seweryna Szmaglewska z pełnym przekonaniem i wiarą przepowiadała, iż jej książa jest zaledwie pierwszym z wielu przyszłych świadectw lagrowych ocaleńców, „którzy wrócą z innych, licznych obozów" ${ }^{1}$. Z pewnością nie potrafiła nawet przewidzieć wówczas jak licznych. Trudno jednak zakładać, by w swojej prognozie uwzględniła także obozy stalinowskie. A przecież, chociaż nieobecne w horyzoncie poznawczym debiutantki i czytelnika krajowego w ogóle, polskie (i kobiece) literackie zapisy doświadczenia stalinowskiego łagru zaczęły się pojawiać równolegle do dzieł lagrowych, dopełniając drastycznie ograniczany pejzaż polskiego i kobiecego losu w czasie wojny. Towarzyszyło im takie samo założenie, ten sam imperatyw dania świadectwa i sformułowania aktu oskarżenia, który, jak wierzyła autorka Dymów nad Birkeanu, „uzupełniony innymi dowodami natchnie on narody wolą unieszkodliwienia mordercy"3. Obawy Szmaglewskiej przed zatarciem „Śladów zbrodni” okazały się przedwczesne i nieuzasadnione wobec zbrodniarzy z Auschwitz, Birkenau, Treblinki, natomiast w pełni słuszne i trafne wobec zbrodniczych twórców Archipelagu GUŁag.

Praca nad Dymami z Birkenau zajęła Szmaglewskiej, jak świadczy data pod ostatnim zdaniem, niespełna pół roku, ukończyła bowiem dzieło, rozpoczęte tuż po ucieczce z "marszu śmierci” w styczniu 1945 roku, w połowie lipca tegoż roku. Jeszcze wcześniej, gdyż już w kwietniu 1945 roku, spisywanie relacji „z otchłani” rocznego osadzenia w Birkenau zakończyła Zofia Kossak, którą wywieziono z lagru wiosną 1944 roku. Jej książka wydana została jednak parę miesięcy po Dymach nad Birkenau. Wszakże prace, i to prace kobiet, nad pierwszymi świadectwami polskiego losu w obozie totalitarnym, jak Tzvetan Todorov ${ }^{4}$ świetnie określił łącznie lagry i łagry, zaczęły się jeszcze wtedy, gdy wspomniane autorki oświęcimskie nawet nie zaznały okrucieństwa życia w obozie koncentracyjnym. Beata Obertyńska swoją książkę wspomnień $\mathrm{z}$ „domu niewoli” i pobytu w łagrze stalinowskim zaczęła pisać w roku 1942, właściwie bezpośrednio po ewakuacji z „nieludzkiej ziemi”. Główna jej część

1 S. Szmaglewska, Dymy nad Birkenau, Warszawa 1978, s. 9.

2 A. Morawiec, Literatura w lagrze, lager w literaturze. Fakt-temat-metafora, Łódź 2009.

3 Świadomość - broń cywilizowanego cztowieka, [Z Seweryną Szmaglewską rozm.] Z. Bigorajska, „Zielony Sztandar” 1961, nr 12, s. 8; cyt. za: A. Morawiec, dz. cyt., s. 181.

${ }^{4}$ T. Todorov, Face à l'Extrême, Paris 1991. 
powstała w następnych latach w Johannesburgu i w Londynie ${ }^{5}$, ale dzieło wydane zostało już po publikacji Dymów nad Birkenau, w roku 1946 w Rzymie. Tylko nieliczni więc czytelnicy polscy mogli poznać tę relację z łagru stalinowskiego. $W$ domu niewoli Obertyńskiej poprzedził jeszcze o kilka miesięcy tom opowiadań Herminii Naglerowej Ludzie sponiewierani, zawierający kilka zbeletryzowanych historii łagrowych, opublikowany niemal jednocześnie z $D y$ mami nad Birkenau. Ale i ta książka wydana została w Rzymie.

I na tym trzeba zakończyć szukanie paraleli genetyczno-wydawniczych. Gdy bowiem obozy hitlerowskie zaczęly zyskiwać status pomników-mauzoleów największej zbrodni w dziejach ludzkości, gdy autorka Dymów nad Birkenau cieszyła się wolnością i słusznie przepowiadała publikację innych świadectw (potwierdzily to Kobiety z Ravensbrück Wandy Dobaczewskiej, Opowiadania oświęcimskie Marii Zarębińskiej), gdy wreszcie, spełniając powinność wobec milionów zamordowanych, występowała jako świadek oskarżenia w norymberskim procesie zbrodniarzy hitlerowskich, a jej książce w owym procesie przypadła rola niemal corpus delicti, w obozach stalinowskich bez nadziei rychłego uwolnienia przebywały miliony zniewolonych, między innymi Urszula Muskus. A Grażyna Lipińska, Barbara Skarga rozpoczynały dopiero dziesięcioletnie łagrowe etapy swojego życia, skazane przez te same władze, których przedstawiciele, oskarżając w Norymberdze zbrodniarzy hitlerowskich, jednocześnie aktywnie uczestniczyli w procesie masowego zaludniania wysp bezkresnego „archipelagu”. Wspomniane autorki długo nie mogły doczekać momentu symbolicznego choćby osądzenia zbrodniarzy stalinowskich, w których ich książkom przypadłaby funkcja podobna do tej, jaką spełniły Dymy nad Birkenau. Oczekiwania na sowiecką Norymbergę, której najpełniejszy wyraz dali Aleksandr Sołżenicyn i Naum Korżawin, oczekiwania na karę za „policzek wymierzony człowieczeństwu” i „policzek wymierzony historii”", jak pisała Lipińska, okazały się płonne. Niemniej jednak po latach pojawiły się książki, niezniszczalne dowody pamięci o ofiarach i ciągle aktualne „prywatne” akty oskarżenia zbrodniarzy. Ukazały się już znacznie później i też poza Polską: Dtugi most Urszuli Muskus w Londynie w roku 1975, trzy lata po śmierci autorki; Po wyzwoleniu... (1944-1956) Barbary Skargi w Paryżu (pod pseudonimem Wiktorii Kraśniewskiej) w roku 1985, wreszcie po kolejnych trzech latach, w roku 1988, również w Paryżu „Jeśli zapomnę o nich ...” Grażyny Lipińskiej.

Wspólnotę doświadczenia obozu totalitarnego, dystansując się przy tym od pokusy „licytacji okropności”, silnie akcentował w roku 1950 Anatol Krakowiecki w Książce o Kotymie. I jako motto ostatniej części dzieła, poświęconej właśnie doświadczeniu łagrowemu, wykorzystał słowa lagrowego $Z$ otchtani Zofii Kossak: „Bóg na to pozwolił niektórym ludziom oglądać piekło za życia

${ }^{5}$ B. Obertyńska (Marta Rudzka), W domu niewoli, Warszawa 1991, s. 356.

${ }^{6}$ G. Lipińska, „Jeśli zapomnę o nich...", Warszawa 1990, s. 7. 
i wrócić, by dali świadectwo Prawdzie”. W kodzie dzieła o „białym krematorium”, jak nazywano łagry kołymskie ${ }^{8}$, silnie podkreślał Krakowiecki „przygniecenie” „tematem Oświęcimia”. W Auschwitz i Kołymie dostrzegał „dwa konary ludzkiej tragedii”, wyrastające z tego samego pnia: „cierpienia bez granic!”. Widział w obozach hitlerowskich i stalinowskich „dwa przeciwne światy” i „dwa przeciwległe bieguny”, ale akcentował ten sam system i „tę samą istotę rzeczy". W enumeracyjnym zestawieniu mnożył, nie tylko w celach retorycznych, analogie, które dowieść miały słuszności tej tezy: „Dymy nad Birkenau” i „dymy nad tajgą”, „lager” i „łagier”, „kapo” i „starosta”, „sonderkomando" i „specizolator”; „muzułman” i „dochodiaga”. Znalazł nawet te same nazwy: „Strafkomando” i „sztrafkomandirówka”, co pozwoliło mu na puentę, akcentującą diabelskość totalitaryzmu: „Jeżeli szatan ma skrzydła, to są właśnie te skrzydła - jednego szatana!"'. Wiele lat po Krakowieckim Barbara Skarga doda jeszcze „zabawne”, jak twierdzi, podobieństwo napisów na bramach obozów totalitarnych: na niektórych hitlerowskich lagrach widniał napis $A r-$ beit macht frei, na sowieckich łagrach: Czestnym trudom odkupaj swoju winu ${ }^{10}$ bądź jakiś jego wariant. W jej książce refleksja nad tą „zabawną” analogią nie została pogłębiona, niemniej jednak wyraźna zdaje się sugestia, wskazanie kierunku poszukiwań.

Kobiece relacje z Birkenau różnią się zasadniczo kompozycyjnie od relacji z łagrów. Albo, jak u Szmaglewskiej, wprowadzają od razu w przestrzeń lagru, albo, jak u Kossak i Krystyny Żywulskiej, rozpoczynają się od momentu opuszczenia Pawiaka (a raczej Serbii ${ }^{11}$ ) i transportu do obozu. Natomiast dzieła, które w dużym uproszczeniu określa się mianem łagrowych, obejmują zazwyczaj całość sowieckiego doświadczenia autorek, a ich kompozycja odtwarza

A. Krakowiecki, Ksiażka o Kotymie, Londyn 1950, s. 239. Arkadiusz Morawiec, przytacza niezwykle cenne spostrzeżenie Władysława Wójcika z przedwojennego jeszcze reportażu Bytem w piekle..., w którym autor stwierdza: „sowieckie obozy koncentracyjne znamy dość dobrze z licznych opisów, jakie im poświęcono. Mniej dobrze znane są niemieckie obozy koncentracyjne, które różnią się od sowieckich tylko tym, że nie znajdują się na syberyjskim bezludziu czy podbiegunowych ziemiach, ale w centrum Europy". Cyt. za: A. Morawiec, dz. cyt., s. 50. Warto przypomnieć, że pierwotna nazwa „obóz koncentracyjny” (w skróconej wersji rosyjskiej „koncłag”) została oficjalnie zamieniona w Rosji sowieckiej w roku 1922 na określenie „obóz pracy poprawczej”; zob. A. Sołżenicyn, Archipelag GUŁag, Próba dochodzenia literackiego, t. 2, autoryzowany przekład z rosyjskiego J. Pomianowski [M. Kaniowski], Warszawa 1990, s. 20-21.

${ }^{8}$ R. Conquest łagry kołymskie nazywał „arktycznymi obozami śmierci”. Por. tenże, Kolyma: The Arctic Death Camps, London 1978.

9 A. Krakowiecki, dz. cyt., s, 248.

10 B. Skarga, Po wyzwoleniu... (1945-1956), Poznań 1990, s. 67.

11 Oddział kobiecy więzienia Pawiak. 
właśnie jego porządek. Wspomnieniową relację rozpoczyna więc najczęściej moment wkroczenia armii sowieckiej, który oznacza terminus a quo nowych, zasadniczo odmiennych, niemal więziennych warunków życia. Późniejsze aresztowanie oznacza w takim ujęciu jakby sformalizowanie statusu więźnia ex definitione. Dopiero w zapisach kolejnych etapów sowieckiego doświadczenia pojawiają się losy łagrowe, wsparte czasem, jak w książce Obertyńskiej, demistyfikowaniem „tak zwanej wolności” ${ }^{12}$ sowieckiej, poznawanej po zwolnieniu z łagru. Autorki bowiem starają się unaocznić łagrowość par excellence państwa stalinowskiego, ukazać Związek Sowiecki jako przestrzeń „wielkiej zony” z rozsypanymi po niej niezliczonymi „małymi zonami” obozów. Łagier wpisany zostaje w tych dziełach $\mathrm{w}$ continuum sowieckiej niewoli, w continuum cierpienia polskiego i indywidualnego. Trzeba czasem pewnego wysiłku czytelniczego, by wychwycić z niego doświadczenie stricte łagrowe. Często opis codzienności więziennej zajmuje $\mathrm{w}$ książkach więcej miejsca niż obrazy rzeczywistości obozowej. I jest to nie tylko zrozumiałe, ale także w pełni adekwatne do indywidualnego doświadczenia autorek: Naglerowa spędziła w różnych tiurmach śledczych i przesyłowych szesnaście miesięcy, Obertyńska około roku, przy „zaledwie” kilkunastotygodniowym stażu łagrowym. Lipińską trzykrotnie ściągano $\mathrm{z}$ obozu do więzienia na wznowienie śledztwa i weryfikację wyroku, po czym kierowano ją do łagru innego, z reguły o sroższym rygorze. Pierwszy transport do łagru z ciężkiego więzienia zdawał jej się drogą „do ziemi obiecanej”" ${ }^{13}$ ale już na miejscu szybko zrodziła się tęsknota za Łubianką. Muskus „zapracowała”, z perspektywy stalinowskiego bezprawia, na łagier już jako osoba wcześniej poddana represjom, jako polski specpierieseleniec.

Powyższe uwagi prowadzą wprost do konstatacji, że refleksja nad zapisami kobiecego doświadczenia w łagrze musi uwzględnić kilka elementów, które mniejszą rolę, jak się wydaje, odegrały w doświadczeniu lagrowym. Polskie świadectwa z lagrów hitlerowskich zamykają się w latach 1941-1945, relacje z łagrów sowieckich obejmują natomiast piętnastolecie 1940-1956. Jeśli jednak spróbowalibyśmy poszerzyć refleksję o doświadczenia więźniarek rosyjskich bądź ukraińskich ${ }^{14}$, to ten okres należałoby znacznie wydłużyć. Otóż uwzględnienie w refleksji nad obozowym losem kobiety „długiego trwania” łagrów, dostrzeżenie istotnych zmian w ich organizacji i statusie, pozwoli zrozumieć przyczyny istotnych różnic w relacjach Obertyńskiej (a także Gustawa Herlinga-Grudzińskiego) i Skargi, Naglerowej oraz Lipińskiej, wytłumaczyć trudności z wychwyceniem i wyartykułowaniem inwariantnych elementów,

12 Beata Obertyńska całą drugą część książki poświęconą dramatycznym losom po zwolnieniu z łagru zatytułowała Na tak zwanej wolności. Por. taż, dz. cyt., s. 197-336.

13 G. Lipińska, dz. cyt., s. 288.

14 W roku 1989 ukazał się w Moskwie rzetelnie udokumentowany zbiór relacji byłych łagiernic Dusza tiagotiejet. Zapiski waszej sowriemiennicy, w polskiej wersji Historie kobiet z Gutagu. Dusza wciąz boli, red. S. Wileński, tłum. A. Kędziorek, Warszawa 2011. 
niezbędnych do szukania podobieństw, ale i różnic między losem kobiet w obozach totalitarnych. Inaczej funkcjonowały łagry w czasie wojny (kiedy przebywały w nich Obertyńska i Naglerowa), inaczej bezpośrednio po wojnie, jeszcze inaczej w latach 1948-1953, kiedy wprowadzono tak zwane specłagry, czyli obozy o surowym reżimie, przeznaczone dla skazanych z paragrafu 58 stalinowskiego kodeksu karnego. Inna była też relacja między liczbą więźniów i więźniarek. W ostatnich latach wojny odsetek kobiet w stalinowskich obozach znacząco się zwiększał; na początku roku 1941 więźniarki stanowiły niespełna 8\% ogółu ,zakliuczonnych”, rok później odsetek ów wyniósł 10\%, w roku 1943 osiągnął wartość ponad 15\%, by pod koniec roku 1944 zbliżyć się do $28 \%{ }^{15}$. A więc w ciągu trzech lat liczba uwięzionych kobiet zwiększyła się trzyipółkrotnie. Wzrost ów łatwo wytłumaczyć wymaganiami wojenny$\mathrm{mi}$, do armii wcielano bowiem nawet mężczyzn z wyrokiem łagrowym, a plan produkcji narzucony obozom musiał być wykonany. $\mathrm{O}$ trafności takiego argumentu „ekonomicznego” świadczy struktura więźniów według płci z początku lat pięćdziesiątych, która przypominała już tę z początku wojny. Ścisłego powiązania funkcjonowania łagrów z bieżącymi wydarzeniami politycznymi dowodzą drastycznie zmiany w poziomie śmiertelności obozowej, które w istotny sposób rzutowały na jego „odbiór” i literackie reprezentacje. W ostatnich latach wojny ten wskaźnik osiągnął wartość najwyższą, przekraczającą, według oficjalnych statystyk $25 \%{ }^{16}$. Dlatego Skarga może z radością podkreślić, że za jej czasów obozowych śmierć już „nie była masowa”, chociaż i tak „było jej zbyt wiele”. I przytacza opowieści łagierników z czasów wojny, kiedy:

układano w stos wynoszone rano z baraku trupy, zmarznięte na kość, przykrywano je śniegiem i czekały na odmarznięcie ziemi, by znaleźć grób. Wtedy jednak panowała pelagra, ta przeraźliwa choroba, która kosi dziesiątkami, a której źródłem jest głód ${ }^{17}$.

Dla powojennego funkcjonowania łagrów najbardziej znaczący wydaje się rok 1948. Na mocy postanowienia władz sowieckich z lutego tego roku ${ }^{18}$ oddzielono wówczas tak zwanych więźniów politycznych od skazańców kryminalnych, zlikwidowano łagry koedukacyjne, aczkolwiek w praktyce zdarzały

15 Stanisław Ciesielski za badaczami rosyjskimi podaje najpełniejsze informacje o strukturze więźniów według płci; odsetek kobiet w łagrach rósł systematycznie od połowy lat trzydziestych, w roku 1934 roku nie osiągnął nawet 6\%. Zob. tenże, GUŁag. Radzieckie obozy koncentracyjne 1918-1953, Warszawa 2010, s. 216, 334.

16 Stanisław Ciesielski za Edvinem Baconem (autorem pracy The Gulag at War: Stalin's Forced Labour System in the Light of the Archives, New York 1994) informuje, że „śmiertelność w obozach osiągnęła najwyższy względny poziom w pierwszej połowie 1943 r., kiedy wynosiła 25,2 proc. w stosunku rocznym”. Tamże, s. 327.

17 B. Skarga, Po wyzwoleniu..., dz. cyt., s. 41.

${ }_{18}$ Zob. S. Ciesielski, dz. cyt., s. 413-415. 
się sytuacje, iż część męska od żeńskiej przedzielona bywała symbolicznie ${ }^{19}$. Takich specobozów, których specyfikę najdoskonalej ujawnił Aleksandr Sołżenicyn w Jednym dniu Iwana Denisowicza, doświadczyły po wcześniejszym pobycie w łagrze „zwykłym” i Lipińska ${ }^{20}$, i Skarga, i Muskus. Osadzonych pozbawiono nazwisk, zastąpiono je numerami. Kobiety, co silnie akcentuje autorka Po wyzwoleniu..., nosity „wykaligrafowane numery” na białych kawałkach materiału wszytych na sukniach z przodu i z tyłu. Miały go także „na watówkach i buszłatach, na watowanych spodniach. (...) Numer wisiał również na deszczułce nad każdą kojką"21.

Z historycznym okresem odbywania wyroku łagrowego łączy się długość obozowego stażu konkretnej łagiernicy-autorki. Determinowała ona w sposób zasadniczy rozumienie mechanizmów panujących w obozie i w konsekwencji sposób jego opisu. Obertyńska i Naglerowa przebywały w łagrze zaledwie kilka miesięcy, natomiast Muskus, Lipińska i Skarga spędziły w obozach „archipelagu” około 10 lat, bez uwzględnienia połagrowego okresu zesłańczego. Najdłuższy, blisko 16-letni staż zesłańczo-łagrowy stał się udziałem autorki Dtugiego mostu. I może właśnie dlatego relacje tych autorek pisane długo i bez pośpiechu, inaczej niż dzieło Obertyńskiej, wolne są od „świeżego wspomnienia krzywdy"22, przepełniającego narrację $W$ domu niewoli. Obertyńska nie ma zahamowań przed formułowaniem zdań, opatrzonych jakby kwantyfikatorem ogólnym, przed którymi wstrzymują się autorki doświadczone długoletnim pobytem. W książce Skargi natomiast, także i u Lipińskiej, więcej jest zapisów refleksji niż emocji. Autorka Po wyzwoleniu... przywołuje tezę psychologów, że „wystarczy posiedzieć w więzieniu trzy lata, aby zaszły zmiany w psychice”23. W łagrze jednak mówiono, że „pięć lat można przestać na jednej nodze”, że nie spowodują one istotnych przemian w człowieku. Ale, jak twierdzi Skarga, „im dalej, tym gorzej. Perspektywa dziesięciu lat jest perspektywą bez granic. (...) Wspomnienia zacierają się. Głowa nie pracuje tak jak dawniej, fakty uciekają, ucieka wiedza, nazwiska, wiadomości”"24. Powiada więc autorka, że dopiero po roku zaczynała cokolwiek rozumieć z łagrowego życia. Dlatego w dziełach kobiet doświadczonych długim stażem

19 Nie dostrzegła tego zróżnicowania Anne Applebaum, która w rozdziale Gutagu poświęconym kobietom i dzieciom w obozie przyjęła jako stałe zasady obowiązujące przez pięć lat i zmienione po śmierci Stalina. „Teoretycznie kobiet i mężczyzn nie powinno trzymać się w łagrze razem i rzeczywiście wielu więźniów twierdzi, że przez całe lata nie oglądało kobiety na oczy". Taż, Gutag, tłum. J. Urbański, Warszawa 2005, s. 298.

${ }^{20}$ Grażyna Lipińska poświęca im całe dwa rozdziały swojej książki. Zob. taż, dz. cyt., s. 364-378, 419-452.

${ }_{21}$ B. Skarga, Po wyzwoleniu..., dz. cyt., s. 118.

${ }^{22}$ G. Herling-Grudziński, Na krawędzi cztowieczeństwa [w:] tegoż, Wyjścia z milczenia, oprac. Z. Kudelski, Warszawa 1993, s. 27.

${ }^{23}$ B. Skarga, Po wyzwoleniu..., dz. cyt., s. 107.

24 Tamże. 
obozowym dostrzec można zasadniczą inność hierarchii problemów, pojawiają się refleksje zupełnie nieobecne bądź ledwo mimochodem zaznaczane w książce „krótkoterminowej” Obertyńskiej, spisującej niemal na bieżąco ciągle żywo raniące wspomnienia dni uwięzienia w łagrze. Skarga i Lipińska, precyzyjne do bólu w opisie beznadziei codzienności łagrowej, co łączy je z Obertyńską, w rekonstrukcji warunków życia i przetrwania, norm żywieniowych i pracy, potrafią jednak spojrzeć z wielu stron, potrafią przekroczyć próg beznadziei. Dzięki takiemu zróżnicowaniu poetyk dzieł łagrowych pisanych przez kobiety czytelnik współczesny może zarówno niemal „na żywo” uczestniczyć w ich doświadczeniu wchodzenia w rzeczywistość łagrową (Obertyńska), jak i jednocześnie poddać je zdystansowanej refleksji (Skarga, Lipińska).

Warto podkreślić jeszcze jeden element różnicujący, w istotny sposób determinujący ogląd obozu i ocenę zachowań więźniarek i ujawniający się $\mathrm{w}$ ich tekstach - wiek łagiernic. Najstarsza z autorek łagrowych, Herminia Naglerowa, w chwili aresztowania miała skończone pięćdziesiąt lat, Beata Obertyńska była kobietą ponad 40-letnią, pięć lat młodsze od niej Grażyna Lipińska i Urszula Muskus zbliżały się do czterdziestki. Ale obie opuściły „nieludzką ziemię" jako kobiety starsze od Naglerowej. Wreszcie najmłodsza pośród nich, Barbara Skarga, w chwili aresztowania była 25-letnią dziewczyną, wyjechała ze Związku Sowieckiego jako kobieta 37-letnia. I tylko ona pisze o miłości, nie tylko o formach zaspokajania pożądania seksualnego, o czym wspominają wszystkie autorki (jedynie we wspomnieniach Muskus ten problem prawie nie występuje), ale o miłości, sposobach jej realizacji, o trwałych związkach w obozie, o pijaństwie na zesłaniu. Ona nie waha się poruszyć kwestii fizjologicznych, pisze o kobiecych chorobach, wykraczających poza „kanon" łagrowy, czyli cyngę bądź pelagrę. Z jej książki dowiemy się o chronicznym, niemożliwym do wyleczenia, ale i lekceważonym przez władze zapaleniu jajników, o braku środków higienicznych i comiesięcznych sposobach radzenia sobie przez kobiety z tym problemem:

czasem jakaś dobra siostra po cichu da kawałek waty. Dziewczyny wydzierają watę z buszłatów, wata jest brudna. Kradniemy w pracowni krawieckiej kawałki starych prześcieradeł, wszystko, co się może nadać ${ }^{25}$.

Ważne dla refleksji nad sytuacją więźnia stalinowskiego łagru jest również uwzględnienie niewyobrażalnej z europejskiej perspektywy i mało ważnej z perspektywy lagrów rozmieszczonych w Europie Środkowej rozpiętości przestrzennej nieobjętego GUŁagu. Jej konsekwencją było ekstremalne zróżnicowanie klimatyczno-przyrodnicze między różnymi łagpunktami, do których

${ }^{25}$ Tamże, s. 113. 
trafiali $\mathrm{w}$ różnych momentach wyroku ci sami skazańcy ${ }^{26}$. Łagry rozciągały się od miejsc położonych daleko poza kołem podbiegunowym do stepów przy granicy sowiecko-chińskiej i pustyń środkowoazjatyckich, od zachodnich osad litewskich (przy granicy z Polska) po najdalej wysunięte punkty Kołymy, Czukotki i Kraju Chabarowskiego. W różnych miejscach „archipelagu", w tym samym czasie kalendarzowym i historycznym, obowiązywały więc zasadniczo różne zasady, które determinowały codzienność obozową. Skarga wraz ze współtowarzyszkami łagru w Komi mogła liczyć na zwolnienie z pracy przy temperaturze poniżej minus 30 stopni Celsjusza, ale Lipińska w Ozierłagu niedaleko Angary pracowała nawet wtedy, gdy temperatura zbliżała się minus 50 stopni. Autorka Po wyzwoleniu... skarży się, że piła elektryczna jest za ciężka dla kobiety, Lipińska zaś na „lesopowale” w swoim obozie nigdy takiej nie widziała. Do ścinania drzew więźniarkom w tym łagrze dawano tylko piły ręczne i siekiery. Różne były także wartości tak zwanego kotła, czyli normy żywieniowe. Stuprocentowe wykonanie normy zapewniało „trzeci kocioł", ale ciężar otrzymywanego za tę pracę chleba wahał się w różnych obozach od kilograma do 700 gramów. Żeby zrozumieć, co znaczy różnica 300 gramów, trzeba wiedzieć, iż taka właśnie ilość chleba stanowiła całodzienny „przydział” („pajok”) więźniów niewypracowujących normy, otrzymujących tak zwany pierwszy kocioł ${ }^{27}$. Podobnego zróżnicowania dowodzą informacje na temat łagrowego przyodziewku. Zasadniczo według „prawa” GUŁagu skazańcy powinni otrzymać „buszłat”, watowaną „tiełogrejkę”, watowane spodnie i walonki, obuwie i rękawice. Według świadectwa Skargi kobiety wraz ze zmianą sezonu dostawały nowe, granatowe sukienki ${ }^{28}$, które starały się przerobić i jakoś ozdobić, zmienić z worków w sukienki właśnie. Lipińska wspomina jednak, że w obozie pod Tajszetem łagiernicy chodzili w łachmanach, w które od momentu aresztowania zmieniła się ich osobista odzież, gdyż nie dostali „regulaminowej” odzieży. Z pewnością można więc stwierdzić, iż geograficzne usytuowanie łagru, determinujące kilkumiesięczne często odcięcie od zewnętrznego „naczalstwa”, w istotny sposób wpływało na warunki pracy, na możliwość komunikacji ze światem, na zaopatrzenie w żywność, w odzież, w narzędzia pracy. Nie doczekaliśmy książkowej relacji polskiej kobiety z Kołymy, fragmenty swoich wspomnień, „raport z Kołymy”,

${ }^{26}$ Kazimierz Zamorski i Stanisław Starzewski już w roku 1945 na podstawie wspomnień zwolnionych łagierników pisali: „Wyżywienie nie jest jednakowe we wszystkich obozach. Zależy ono od warunków miejsca i czasu. (...) W 1940 roku nastąpiło pogorszenie, pogłębiające się szybko i w 1941 roku śmierć głodowa (...) stała się zjawiskiem codziennym”. Ci, Sprawiedliwość sowiecka, Warszawa 1994, s. 114.

${ }_{27}$ Tamże, s. 154. W wydanej w języku angielskim książce (The Dark Side of the Moon, wstęp T.S. Eliot, New York 1947, s. 140) anonimowy(a) autor(ka) zacytował(a) fragment „protest-songu” łagrowego: „A kak nie vipolnish normu,/ Tolko trista gram khleba dadut”.

28 B. Skarga, Po wyzwoleniu..., dz. cyt., s. 113. 
opublikowała jedynie Teodozja Lisiewicz ${ }^{29}$. Na tym „biegunie okrucieństwa”, na który, jeśli wierzyć autorce raportu, trafiło 6 Polek, „kobiety (...) trzymały się stosunkowo dobrze" ${ }^{30}$, mimo niemożliwych do zrealizowania norm pracy. W ciagu jedenastu godzin w lodowni dwie kobiety powinny zasolić 6600 sztuk łososia ważącego $5-7 \mathrm{~kg}$ lub oczyścić 1700 sztuk. Za wykonanie normy otrzymywały 700 gramów chleba i zupę „z rybnej głowy lub z kaszy zarzuconej na wodę" 31 .

Nawet taki krótki przegląd warunków łagrowych odzwierciedlonych w dziełach polskich autorek zmusza do konstatacji, iż tylko pozornie takie same doświadczenia obozowe w rzeczywistości zasadniczo się różniły. A owe różnice w „szczegółach” decydowały częstokroć o przeżyciu. Świadomość ich znaczenia uniemożliwia wręcz wypracowanie jakiejś jednej formuły, zamykającej łagrowe doświadczenie kobiet, zmusza do wstrzemięźliwości w artykułowaniu wniosków, do uwzględnienia wszystkich determinant losu obozowego: historycznego, czasowego, politycznego, geograficznego, organizacyjnego. W każdym jednak przypadku zawsze bardzo trudnego i nieludzkiego.

Polską wizję kobiety w łagrze sowieckim w największym stopniu ukształtował i, niestety, utrwalił, mężczyzna, autor Innego świata. Wynika to oczywiście bezpośrednio ze znaczenia dzieła Gustawa Herlinga-Grudzińskiego w kreowaniu polskiego, bardzo skądinąd wąskiego, wyobrażenia obozu stalinowskiego. Trudno jednak zaakceptować sytuację, w której łagrowe życie kobiety zostaje ograniczone li tylko do roli obiektu seksualnego, a w taki właściwie sposób przedstawia je autor Innego świata. Dramatyczne losy łagiernic prezentuje Herling w niezwykle przejmujących historiach czterech kobiet: pięknej i młodziutkiej Polki, „gienieralskoj doczki”, zagłuszającej swoistą obozową „nimfomanią” klęskę w beznadziejnej próbie dochowania czystości i wierności sobie; Marusi, ofiary zbiorowego gwałtu urków, czystym oddaniem wobec prowodyra przezwyciężającej hańbę zbrodni; moskiewskiej śpiewaczki Tani, która miała nieszczęście spodobać się brygadierowi „urce” i długo broniła się przed obozową nieuchronnością kobiecego losu, wreszcie Jewgienii Fiodorowny, pielęgniarki,

29 T. Lisiewicz, Raport z Kotymy [w:] W czterdziestym nas matko na Sibir zestali. Polska a Rosja 1939-42, wybór, oprac. J.T. Gross, I. Grudzińska-Gross, wstęp J.T. Gross, Warszawa 1990, s. 426-439. Kołymskie wspomnienia w języku angielskim, opatrzone inicjałami T.L., faktograficznie identyczne z raportem Lisiewicz, odnajdziemy w książce The Dark Side of the Moon, dz. cyt., s. 193-206.

${ }^{30}$ T. Lisiewicz, dz. cyt., s. 435. Ale los kobiety na Kołymie doczekał ważnego świadectwa, głos Eugenii Ginzburg w Stromej ścianie brzmi bowiem przejmująco i przekonująco. Zresztą jedną z najwcześniejszych relacji z Kołymy napisała także kobieta - Elinor Lipper.

31 Tamże, s. 431. 
która prawdziwą miłością wyzwoliła się z upokarzającej relacji z lekarzem obozowym. Nawet w historii Natalii Lwowny, „nałogowej” czytelniczki Zapisków z martwego domu, podkreśla Herling jej „brzydotę”, która uchroniła ją przed „torturą pracy”, przymuszającej do seksualnej „uległości” ${ }^{2}$. Autor Innego świata nie oskarża kobiet, oskarża warunki obozowe, w których one żyły, ale nie dostrzega właściwie kobiety w innych sytuacjach. I pozwala sobie na wyartykułowanie kontrowersyjnej tezy, że kobiety gorzej znosiły głód seksualny, dlatego ze stronic Innego świata wyłania się zasadniczo obraz niewolnicy seksualnej, podporządkowanej całkowicie mężczyźnie, mającemu jakąś pozycję w łagrze: „pridurkowi” bądź „urce”. Dlatego nie wstrzymuje się Grudziński przed przytoczeniem okrutnej, „prostej prawdy życia obozowego”, która głosiła, iż „łamiąc opierającą się kobietę głodem fizycznym, zaspokaja się jej obie potrzeby naraz" ${ }^{33}$. Neutralizując nieco brutalność tej tezy, wspomniał o przeniesionej do moralności łagrowej hipokryzji ze świata wolnego, poniżającej więźniarkę oddającą się z głodu, ceniącej natomiast łagiernika, który dla poprawienia warunków obozowej egzystencji stawał się kochankiem lekarki obozowej.

Mniej z tą wizją, bardziej z postawą uprzedmiotowiającą kobiety, także ze skłonnością do generalizowania, polemizowała Barbara Skarga (cytując zresztą wyjątkowo okrutne słowa wulgarnej czastuszki bratniackiej: „Od Suchumi do Batumi szarki katała/ Jeslib nie było p...y s głodu propała" ${ }^{34}$ ), najpierw w mądrych refleksjach nad Innym światem, potem, znacznie bardziej przekonująco, w książce Po wyzwoleniu... W ocenie dzieła Herlinga dowodziła ona, iż „nie jest (...) prawdą, że można było mieć każdą kobietę za pajdkę chleba”. Podkreślała, że wiele kobiet „trzymało się dzielnie, nieraz nad podziw. O tej postawie decydował raczej nie głód, ale wpojone zasady moralne, związane z kręgami kulturowymi” ${ }^{35}$. I jako przykład podawała postawy Polek, Ukrainek z zachodniej Ukrainy, Litwinek, Estonek, przeciwstawiając im kobiety kształtowane duchowo w czasach sformułowanej przez Aleksandrę Kołłontaj „nowej moralności seksualnej klasy robotniczej”36, w której stosunek płciowy traktowany był jako jedna $\mathrm{z}$ „najprostszych fizjologicznych potrzeb”37.

Pobieżna lektura łagrowych dzieł pisanych przez kobiety może wszakże skłonić do wniosków bliskich przekonaniom Herlinga. Obertyńska skwapliwie notuje lubieżne rozmowy kobiet w szpitalu, radujących się ciemnościami

32 G. Herling-Grudziński, Inny świat. Zapiski sowieckie, Warszawa 1998, s. 240.

33 Tamże, s. 199.

${ }^{34}$ B. Skarga, Po wyzwoleniu..., dz. cyt., s. 137.

${ }_{35}$ Taż, Świadectwo „Innego świata”, [w:] Herling-Grudziński i krytycy. Antologia tekstów, wybór, oprac. Z. Kudelski, Lublin 1997, s. 202.

${ }^{36}$ A. Kołłontaj, Stosunki między ptciami a walka klas, tłum. M. Turowski, „Lewą Nogą” 2004, nr 16; cyt. za: http://www.filozofia.uw.edu.pl/skfm/publikacje/kollontaj02.pdf, dostęp: 7.01.2018; zob. też J. Sadowski, Rewolucja i kontrrewolucja obyczajów. Rodzina, prokreacja i przestrzeń życia w rosyjskim dyskursie utopijnym lat 20. i 30. XX wieku, Łódź 2005, s. 25-35.

37 B. Skarga, Po wyzwoleniu..., dz. cyt., s. 129. 
w barakach, dzięki którym „każda ładna, z zębami czy bez. Im krótszy dzień, tym dłużej jesteś ładna" ${ }^{38}$. Nie kryjąc zniesmaczenia, jeśli nie wręcz obrzydzenia, autorka komentuje:

Jest $\mathrm{w}$ tych opowiadaniach krowie lenistwo i bierność. (...) Tępe poddanie się instynktowi, który (...) nie jest nawet decydującym bodźcem przy kojarzeniu się tych przypadkowych łagiernych stadeł. Swatem bywa najczęściej głód i wyrachowanie ${ }^{39}$.

Z jednakim niesmakiem pisze Obertyńska o „dzikich i rozpasanych”, ocenianych ze skrajną niechęcią dziewczynach z Zakarpacia, które, bardziej ze swojej „zwierzęcej” natury niż z wyrachowania, oddają się „bezwstydowi posuniętemu do rajskiej prostoty w biały dzień i w białe noce" ${ }^{40}$. Lipińska też stwierdza, że młode kobiety „,kkuszone chlebem i lżejszą pracą” „prędzej czy później, idą na żer pridurków, jeśli nie chcą stać się żerem pitagry" ${ }^{31}$. Przecież jednak wizerunki kobiet wykreowane w książkach, także opisy ich obozowych postaw stanowią jawne zaprzeczenie tej tezy.

Dzieła byłych łagiernic, nie kwestionując bynajmniej znaczenia kontaktów seksualnych, nie ograniczają się jedynie do tej sfery życia. Unaoczniają niezwykle trudną obozową egzystencję kobiet, obejmującą ich pracę ponad możliwości fizyczne, życie w łagrze ze wszystkimi jego przejawami (znacznie bogatsze w detale od tekstów męskich), walkę o przetrwanie, o zachowanie godności. Anne Applebaum, skupiona co prawda, trochę jak Herling, na łagrowym bezprawiu seksualnym, konstatowała jednak w Gutagu, iż kobiety:

wyrabiały te same normy, jadły tę samą wodnistą zupę. Żyły w takich samych barakach i transportowano je w takich samych wagonach bydlęcych. Nosiły taką samą odzież i równie niewygodne buty. Tak samo traktowano je w śledztwie. Mimo to sytuacja kobiet w obozach była inna niż mężczyzn ${ }^{42}$.

Inność dla autorki Gułagu raz znaczy lepszość, innym razem gorszość. Ze wspomnień więźniarek rosyjskich zebranych w tomie Dusza tiagotiejet. Zapiski waszej sowriemiennicy Applebaum próbuje wnioskować, iż „fakt bycia kobietą działał w systemie obozów sowieckich na ich korzyść" ${ }^{3}$. Bardziej dbały o siebie, mężniej znosiły głód, trudniej od mężczyzn zapadały na choroby. Amerykańska autorka przywołuje jednocześnie historię młodej Polki opowiedzianą przez Herlinga, która prowadzi do wniosków odmiennych. Otóż

\footnotetext{
38 B. Obertyńska, dz. cyt., s. 164.

39 Tamże, s. 166.

40 Tamże, s. 151.

${ }^{41}$ G. Lipińska, dz. cyt., s. 293.

${ }^{42}$ A. Applebaum, dz. cyt., s. 296.

${ }^{43}$ Tamże.
} 
takie równoległe zestawienie jednoznacznie dowodzi, iż próby „wartościowania” muszą być skazane na niepowodzenie, iż są poznawczo jałowe. Od pokusy wyciągania zbyt pośpiesznych wniosków ważniejsza z pewnością zdaje się „rekonstrukcja” łagrowego świata kobiety. Oczami więźniarek „krótkoterminowych" i tych z bardzo długim stażem łagrowym, skupionych na doświadczeniu jednostkowym i próbujących uchwycić „fenomenologię” łagru.

Obertyńska przyjechała do obozu po rocznym pobycie w więzieniach, po trwającym miesiąc transporcie ze Starobielska do Workuty. Trafiła do obozu, za kołem podbiegunowym, który istniał od roku. I, jak powtarza za łagiernikami, którym przypadł nieszczęsny los pionierów, miała szczęście. W styczniu 1940 roku na miejscu obecnego obozu „nie było (...) nic prócz wichru, śniegu i 60 stopni mrozu. Pierwsze ognisko w śniegach rozłożyli tam oni i oni sklecili pierwszy szałas. Zaraz też pierwszej zimy wymarzła ich połowa”" ${ }^{\prime 4}$. Przed kilkunastokilometrową pieszą wędrówką do miejsca przeznaczenia łagiernice otrzymały „kazionną bieliznę”: „po jednej męskiej koszuli i jednej parze takichże kalesonów z surówki”, po których „łaziły wszy jak bób” ${ }^{5}$. Wcześniej bania z wodą w szaflikach „tak ohydnie śliskich od cudzych mydeł i brudów, że aż się mdło robiło". Przezwyciężyła Obertyńska obrzydzenie uświadomieniem sobie własnego stanu, bycia „takim samym łachem jak ci wszyscy, którzy się tu myli przed tobą. A może jeszcze obrzydliwszym", wyzbyciem się „przeczulenia na własnej osobie, własnym ciele, własnej skórze”46. Obertyńska wraz z 350 kobietami: Polkami, Żydówkami, zakarpackimi Ukrainkami została przeznaczona do folwarku w tundrze, „tzw. skot-dworu, gdzie się prowadzi mleczne gospodarstwo na wielką skalę". Przebywała w nim niedługo, gdyż wkrótce dzięki pomocy ukraińskiego lekarza-więźnia trafiła do sangorodka, szpitala oddalonego kilkadziesiąt kilometrów od Loch-Workuty. Szczegółowo jednak opisała warunki egzystencji i pracy w rolniczym łagrze za kołem podbiegunowym. Częśc łagiernic ulokowano w dużych, zapluskwionych barakach, resztę, w tym narratorkę, skierowano do płóciennej pałatki, porównanej do olbrzymiej purchawki. Nie było w nim żadnego oświetlenia, jedyne światło przebijało się przez płótno ściany. Obertyńska przebywała w Workucie w okresie lata i białych nocy, nie doświadczyła więc zimna i ciemności. Ze względu na tumany komarów prymitywne drzwi właściwie nie były otwierane; żeby wejść do namiotu kobiety musiały wczołgiwać się na czworakach, pod kawałkami brezentu zasłaniającymi dodatkowo otwór drzwiowy.

${ }^{44}$ B. Obertyńska, dz. cyt., s. 139.

45 Tamże, s. 143.

46 Tamże, s. 140. 
Nic dziwnego, że namiot ów i warunki w nim panujące porównała Obertyńska do psiej budy. Stało w niej kilka rzędów niziutkich dwupiętrowych nar pokrytych witkami krzewów. Podłogę, raczej klepisko, gdzieniegdzie pokrywały przegniłe deski, pośrodku ustawiony był żelazny piecyk, w kącie dziurawy cebrzyk. I w takich warunkach żyło 60 kobiet.

W relacjach Lipińskiej czy Skargi nie znajdziemy tak szczegółowych opisów. Wieloletni wyrok, jaki odbywały, dość częste zmiany łagrów pozwoliły dokładniej poznać „archipelag” i jego specyfikę, nie tylko z autopsji, ale także dzięki opowieściom innych uwięzionych. Dawało to możność dostrzeżenia podobieństw, ale także uchwycenia różnic $i$, co ważniejsze, prowadziło do niezwykle istotnej zmiany perspektywy oglądu i oceny z „zawsze" na „,zasem”" ${ }^{77}$. Bo jeśli Skarga w pierwszym obozie, w litewskich Prawieniszkach ${ }^{48}$, w którym kobiety poddawane były „selekcji” i „tylko sztuki zdrowe i silne miały szansę" ${ }^{\prime 9}$, żyła w stanie ciągłego niedożywienia i, ciężko pracując fizycznie, zaczęła „dochodzić”, to w azjatyckim obozie w Bałchaszu, co silnie akcentuje, przeżyła nienajgorszy okres łagrowego życia: „Nie byłam w baraku, mogłam zgasić światło, szczęście każdego więźnia. Nie byłam głodna" ${ }^{0}$. Doświadczenie pracy w czterech łagrach na najróżniejszych stanowiskach, od robót ogólnych, wycinania drzew na „lesopowale” czy rąbania skał przy budowie nasypów kolejowych, po funkcję „,normirowszczyka” bądź „lekpoma”, więc przedstawiciela łagrowej „arystokracji”, pozwoliło jej ze spokojem powiedzieć, że są obozy, które nie stwarzały szans na przeżycie i te lepsze, (...) gdzie, jak to się mówiło, wprawdzie się nie żyje, ale egzystować można"51. Owe doświadczenia zmuszały do rezygnacji z posługiwania się kryteriami „obiektywnymi”. Dlatego podkreśla Skarga brak jakiejś jednej „reguty” kwalifikującej, dlatego ze spokojem twierdzi, że „wszystko zależy od szczęścia” ${ }^{2}$. „Lepszymi” były „wielkie” obozy, w których panował „słaby rygor”, istniała „możliwość urządzenia się” i „wyfasowania lepszego ubrania, walonek". Częściej spotykano tam przedstawicieli rosyjskiej jeszcze inteligencji, także sowieckiej „niszczonej od rewolucji po wojnę" ${ }^{33}$. Skarga przebywała i w jednych, i w drugich; poznała łagry koedukacyjne, w których liczba kobiet i mężczyzn była w miarę podobna, doświadczyła również życia w obozie, w którym na 2000 więźniów przypadało zaledwie kilka łagiernic. Najdłużej jednak była w obozie kobiecym, w którym świat mężczyzn reprezentowało tylko „naczalstwo”. Poznała też historie kobiet, które miały „mniej szczęścia”, które „całe lata spędzały na wędrówkach z kolonii do kolonii, z jednego łagpunktu do drugiego". Mimo niewielkich odległości

\footnotetext{
47 B. Skarga, Po wyzwoleniu..., dz. cyt., s. 97.

48 Autorka konsekwentnie używa wersji Prawianiszki.

49 B. Skarga, Po wyzwoleniu..., dz. cyt., s. 75.

50 Tamże, s. 28.

51 Tamże, s. 26.

52 Tamże, s. 83.

53 Tamże, s. 48.
} 
dzielących owe „łagpunkty” każda zmiana miejsca oznaczała stratę rzeczy niezbędnych do funkcjonowania, „błatniaczki” zabierały im wszystko.

Bogata w takie doświadczenia i taką „wiedzę” obozową Skarga przekracza horyzonty poznawczo-wspomnieniowe innych autorek. Nie znaczy to, że pomija "kanoniczne” elementy narracji łagrowej, niezwykle sugestywnie unaocznia upiorną powtarzalność obozowego „dnia po dniu”, wywołującą poczucie absolutnej beznadziei. Porażają w jej wspomnieniach opisy morderczej pracy kobiet na robotach „ogólnych”: przy wycince drzew bądź kuciu skał pod nasyp kolejowy w temperaturze około minus 30 stopni (o wartości temperatury decydowało „naczalstwo”) i silnym wietrze. Lipińska mówi o „nieograniczonym" czasie pracy, przed którym nie chroniła nawet daleko posunięta gruźlica, ponieważ ,jest chorobą chroniczną" ${ }^{54}$. Skarga ujawnia przy tym niespodziany, szczególnie w kontekście innych dzieł obozowych, także lagrowych, akcentujących markowanie pracy, szacunek do owego niewolniczego wysiłku. Potrafi docenić harówkę, zauważa, że praca może być dla więźnia niszcząca, ale może też wzmacniać i dodawać sił. W „uznaniu pracy za swoją”, w odnalezieniu w niej wiary w siebie więźniarki, jak przekonuje Skarga, widziały jedyną formę powiedzenia „nie” systemowi, traktowały to jako rodzaj „wyzwolenia się" z opresji, przy jednoczesnym zyskaniu „podziwu ciemiężycieli”"5s. Dlatego autorka Po wyzwoleniu... nie ukrywa radości z każdorazowego przekroczenia normy, przeciwstawienia się wszechobowiązującej w łagrze „tufcie” (oszustwa), w którym akcentowała własną, ale również europejską niechęć do kłamstwa.

$\mathrm{Na}$ przykładzie żeńskiego obozu produkującego cegły podejmuje Skarga próbę przeprowadzenia, sui generis, analizy ekonomicznej, dowodząc, jak ,intratną gospodarczo instytucją" ${ }^{\prime 6}$ były sowieckie obozy i jak ważną rolę w tej „instytucji” miały do odegrania kobiety: „trzysta osób pokrywało całkowicie koszt utrzymania ponad 2200 osób, a więc cały żeński plus 200 osób”57. Wspiera swoje refleksje analizą dietetyczną, wylicza precyzyjnie normy żywieniowe w obozie, podaje gramaturę wszystkich produktów spożywczych: jarzyn, kaszy, tłuszczu, cukru, ryby, wykazując, że 1,5 litra zupy, zgodnie z normą, należało ugotować z 15 gramów kaszy, 150 gramów jarzyn (kapusty) i 10 gramów tłuszczu. Razem z chlebem i 5 gramami cukru dawało to dziennie 1615 kalorii. Ciężko pracująca kobieta potrzebuje tych kalorii 3200. Ale nawet tych głodowych norm nie przestrzegano, gdyż niemałą część produktów kradli funkcyjni różnego szczebla. Skarga akcentuje niezwykłą zapobiegliwość więźniarek tak zwanych politycznych, ich pomysłowość. Potrafiły bowiem uprząść wełnę z pakuł przeznaczonych do izolacji ścian. Dzięki temu mogły swoją ubożuchną odzież wzbogacić w nowe swetry i skarpety. Podkreśla

54 G. Lipińska, dz. cyt., s. 375.

55 B. Skarga, Po wyzwoleniu..., dz. cyt., s. 98.

56 Tamże, s. 69-70.

57 Tamże, s. 108. 
też troskę współwięźniarek z paragrafu 58, choć ich nie idealizuje, o zachowanie czystości w ekstremalnie niesprzyjających temu okolicznościach, ciągłe pranie nie tylko bielizny, ale także koców, sienników, nawet tych wypchanych strużkami drzewa.

W „wielkich obozach”, jak zauważa Skarga, „była (...) szansa na miłośc” 58 , aczkolwiek więźniowie przyłapani na intymnych kontaktach karani byli karcerem, a nawet etapem do innego łagru. Pisze autorka o potrzebie kontaktu z bliską osobą, tęsknocie za ciepłym słowem, które pozwalało łatwiej przetrwać w „chłodzie wzajemnej obojętności” ${ }^{9}$. Z dużą empatią, inaczej niż Obertyńska, odnosi się do kobiet, które "poniosły tragiczne skutki nawet krótkiej chwili zapomnienia" ${ }^{\circ 0}$. Jeszcze w czasie pobytu w łagrze dokonała wraz ze współwięźniarkami klasyfikacji miłości obozowych. Pierwszą stanowiła miłość „zakonnaja”, czyli związek prawowitych małżonków, kolejną - miłość ludzi żyjących w nieformalnym związku obozowym, tak zwanych żenatików, której sens zawierał się w realizacji ustalonych wcześniej „usług”. Zdrady w takich związkach bywały surowo karane, mógł to być gwałt zbiorowy, ale często nawet śmierć. Wreszcie miłość homoseksualna, lesbijska nazywana w łagrze miłością „kobłów”. Rozpowszechniła się przede wszystkim po roku 1948, w specłagrach, po likwidacji obozów koedukacyjnych. Powszechna była także prostytucja, uprawiana jednak poza zoną.

Z kontaktami seksualnymi łączyło się wprost zagrożenie chorobą weneryczną i jeszcze większe niebezpieczeństwo ciąży. Niebezpieczeństwo, ponieważ dziecko urodzone w łagrze odbierane było matce i trafiało do sierocińca. Tylko niektórym „urkaczkom” zależało na utrzymaniu ciąży, ciężarna bowiem przenoszona była do lżejszej pracy i dostawała 200 gram mleka. Większość brzemiennych więźniarek poddawała się zabiegowi aborcji, prymitywnie przeprowadzanemu (w ówczesnej Rosji sowieckiej była ona zakazana prawem) często kończącym się śmiercią kobiety. Obertyńska tłumaczyła to prawo jako obawę przed „ucieczką z tiurmy!”. „Bo w Rosji naprawdę ma się wrażenie, że tylko $\mathrm{z}$ tego punktu widzenia przedstawia życie ludzkie jakąkolwiek wartość" ${ }^{61}$.

W pytaniach Skargi: „czy w ogóle jest możliwe oddanie tamtych nastrojów, lęków, tęsknoty, cierpienia. Czy można je sobie wyobrazić, jeżeli się ich nie przeżyło?" ${ }^{2}$, słyszę nie tylko niepokój autorki przed reakcją czytelnika, ale

\footnotetext{
58 Tamże, s. 43.

59 Tamże, s. 135.

60 Tamże, s. 129.

61 B. Obertyńska, dz. cyt., s. 96.

62 B. Skarga, Po wyzwoleniu..., dz. cyt., s. 103.
} 
także mądrą radę, może przestrogę przed pochopnością sądów, przed nadmierną skwapliwością oceny. Słyszę wreszcie prośbę o empatię, która powstrzymuje przed próbą jakichkolwiek porównań ekstremalnych doświadczeń kobiety-häftlinga i kobiety-zeka, przed pokusą poddania się nieludzkiej „licytacji okropności”. W upiornej rzeczywistości obozu kobiety podobnie walczyły o przetrwanie, podobnie cierpiały głód, podobnie chorowały, choć może na inne choroby. Podobnie pragnęły ciepła oraz miłości i ponosiły jej straszliwe konsekwencje.

Relacje polskich kobiet z lagru bądź łagru bez trudu dałyby się usystematyzować. I taki moment z pewnością nastąpi. Wykazane zostaną podobieństwa (czasem różnice) w lagrowo-łagrowej sytuacji więźniarek, wyszczególnione „normy” pracy i żywienia. Wychwycone zostaną analogie w poetyce, sposobach mówienia o doświadczeniu obozu totalitarnego (na przykład Naglerowa i Szmaglewska), pokrewieństwa ideowe (Obertyńska i Kossak). Na razie jednak ważniejsze wydaje się dostrzeżenie i zaakcentowanie ich komplementarności. Czytane bowiem razem ujawniają w pełni janusowe oblicze okrutnego stulecia obozów koncentracyjnych i zmagania z nim kobiet, „równouprawnionych" z mężczyznami w roli ofiary.

\section{Bibliografia}

Applebaum A., Gutag, tłum. J. Urbański, Warszawa 2005.

Ciesielski S., GUŁag. Radzieckie obozy koncentracyjne 1918-1953, Warszawa 2010. Conquest R., Kolyma: The Arctic Death Camps, London 1978.

Herling-Grudziński G., Inny świat. Zapiski sowieckie, Warszawa1998.

Herling-Grudziński G., Wyjścia z milczenia, oprac. Z. Kudelski, Warszawa 1993. Historie kobiet z Gutagu. Dusza wciaż boli, red. S. Wileński, tłum. A. Kędziorek, Warszawa 2011.

Kołłontaj A., Stosunki między ptciami a walka klas, tłum. M. Turowski, „Lewą Nogą" 2004, nr 16.

Krakowiecki A., Ksiażka o Kotymie, Londyn 1950.

Lipińska G., „Jeśli zapomnę o nich...", Warszawa 1990.

Lisiewicz T., Raport z Kotymy [w:] W czterdziestym nas matko na Sibir zestali. Polska a Rosja 1939-42, wybór, oprac. J.T. Gross, I. Grudzińska-Gross, wstęp J.T. Gross, Warszawa 1990.

Morawiec A., Literatura w lagrze, lager w literaturze. Fakt-temat-metafora, Łódź 2009.

Muskus U., Dtugi most. Moje przeżcia w Zwiazku Sowieckim: 1939-1956, przedm. Jan Pirożyński, Londyn 1975.

Naglerowa H., Ludzie sponiewierani, Rzym 1945.

Obertyńska B. (Marta Rudzka), W domu niewoli, Warszawa 1991.

Sadowski J., Rewolucja i kontrrewolucja obyczajów. Rodzina, prokreacja i przestrzeń życia w rosyjskim dyskursie utopijnym lat 20. i 30. XX wieku, Łódź 2005. 
Skarga B., Po wyzwoleniu... (1945-1956), Poznań 1990.

Skarga B., Świadectwo „Innego świata”, [w:] Herling-Grudziński i krytycy. Antologia tekstów, wybór, oprac. Z. Kudelski, Lublin 1997.

Sołżenicyn A., Archipelag GUŁag, Próba dochodzenia literackiego, t. 2, autoryzowany przekład z rosyjskiego J. Pomianowski [M. Kaniowski], Warszawa 1990.

Szmaglewska S., Dymy nad Birkenau, Warszawa 1978.

The Dark Side of the Moon, wstęp T.S. Eliot, New York 1947.

Todorov T., Face à l'Extrême, Paris 1991.

Zamorski K., Starzewski S., Sprawiedliwość sowiecka, Warszawa 1994. 